\title{
TAMAN SELUNCUR INTERAKTIF SETIABUDI
}

\author{
Stefanny Makmur ${ }^{1)}$ \\ 1) Program Studi S1 Arsitektur, Fakultas Teknik, Universitas Tarumanagara, stefannymakmur30@gmail.com \\ Masuk: 10-01-2020, revisi: 27-01-2020, diterima untuk diterbitkan: 09-05-2020 (doi: 10.24912/stupa.v2i1.6853)
}

\begin{abstract}
Abstrak
Duncan M. Laren dan Julian Agyeman mengatakan dalam karya penulisannya mengenai 'sosiokultural' yang merupakan sifat dasar manusia terjadi di mana saja namun kini semakin lama masyarakat mengalami perpecahan ketika mengenal komersial publik dan aspek ekonomi serta teknologi yang berkembang pesat. Berbagai tren yang terkait dengan hal-hal komersial perlahan menciptakan destabilisasi dan fragmentasi akan identitas pada sebagian masyarakat, maka terdapat klasifikasi kelas yang terbentuk diantaranya. Dari berbagai kesempatan yang ada dalam sebuah kota, terkadang terjadinya kesalahgunaan yang berfokuskan pada ketertarikan ekonomi, alhasil kepentingan masyarakat dikesampingkan akibat ruang-ruang yang tersedia diperuntukan menjadi commercial interest yang memprivatisasi layanan publik dan memanfaatkan value tanah dengan cara gentrifikasi. Sebuah Third place yang menyediakan serangkaian aktivitas merupakan salah satu tanggapan arsitektural dalam pembangunan masyarakat yang terbuka. Melalui apresiasi warga yang tinggi terhadap olah raga dan kuliner sebagai daya tarik yang sesuai dengan karakteristik kawasan, program yang ditawarkan ialah penggabungan dan pengembangan kegiatan dasar. Proyek ini diharapkan mendukung pembudidayaan akan kegiatan skateboard dan aktivitas serupa seperti bersepeda, sepatu roda, serta jenis olah raga basic yang dapat diikuti oleh semua orang, mengambil dari kategori olah raga seluncur, proyek ini mengangkat program dry ski, di mana program ini memiliki potensi dalam kawasan tersebut. Mengendalkan metode tipologi kegiatan dan trans-programming serta sumber konsep yang dekemukakan oleh Edward T. White, proyek dengan desain layout flexible menciptakan removable Dry ski yang menjadi bagian dominan dalam program third place untuk membangun masyarakat aktif pada lokasi yang sangat berpotensi dengan sistem TOD yang kuat.
\end{abstract}

Kata kunci: fragmentasi sosial; individualisme; komersial; third place

\begin{abstract}
Duncan M. Laren and Julian Agyeman stated in their writings on 'sociocultural' which is a human nature that occurs everywhere but now society is gradually divided when it comes to public commercial knowledge and the rapidly developing economic as well as technological aspects. Various trends related to commercial matters are slowly creating destabilization and fragmentation of identity in some societies, as there are class classifications formed among them. Of the various opportunities that exist in a city, sometimes misuse that focuses on economic interest, as a result the interests of the community are ruled out because the available spaces are intended to be commercial interests that privatize public services and utilize land values by means of gentrification. A Third place that provides a series of activities is one of the architectural responses in the development of an open society. Through the high appreciation of the community for sports and culinary as an attraction that is in accordance with the characteristics of the area, the program offered is the incorporation and development of basic activities. This project is expected to support the cultivation of skateboarding activities and similar activities such as cycling, rollerblading, and basic types of sports that can be followed by everyone, taking from the category of skating, this project promotes a dry ski program, where this program has potential in the region. Restraining the methodology of activity typology and trans-programming as well as the source of the concepts presented by Edward T. White, the project with flexible layout design creates removable dry skiing which is a dominant part of the third place program to build active communities in locations with high potential with a strong TOD system.
\end{abstract}

Keywords: commercial; individualism; social fragmentation; third place 


\section{PENDAHULUAN}

\section{Latar Belakang Proyek}

Dewasa ini, berfokuskan di Jakarta, hubungan sosial semakin renggang tidak jauh dari perihal dengan kehidupan masyarakat yang berbatasi kotak dalam kubikel, terpartisi, spesialisasi, apertemen, dan clustered. "Faktanya ada faktor eksternal yang mengondisikan seseorang menjadi pribadi yang individualis," ungkap Penelity $\mathrm{MCl}$ (Merapi Cultural Institute) Gendhotwukir (Nisrina, 2016). Serangkaian faktor yang mempengaruhi masyarakat berdifat individualis ialah revolusi industri, transportasi, teknologi, dan pasar, dimana utamanya dalam pergeseran dari agrasi ke industri yang berdampak kenaikan pesat ekonomi positif namun secara tidak langsung berdampak buruk dalam segi sosial. Secara garis besar, arogansi kaum industrial perlahan mulai memiliki sifat indivisualisme tinggi hingga munculnya strata kelas dalam masyarakat, dikarenakan minimnya kebersamaan yang berawal dari kecenderungan memprioritaskan diri sendiri, sebaliknya tidak memberi perhatian pada individu lain.

Dalam faktor industrial yang sangat mempengaruhi yaitu jenis pekerjaan yang memiliki rutinitas bagi warga yang bekerja dari pagi hingga pulang malam pada hari kerja, dan hanya memiliki waktu luang dengan keluarga di waktu pekan. Diluar dari kepribadiaan masing individu yang beragam, rutinitas dan kesibukan yang melanda yang berperan besar dalam pembentukan sifat yang tertutup. Hal ini dapat dikoneksikan dengan keinginan bersosialisasi yang akhirnya lebih sering terjalin melalui media sosial. Menurut salah satu pendiri RBKM (Rumah Baca Komunitas Merapi) masyarakat walaupun memiliki sifat individualisme yang tinggi akibat era globalisasi serta modernisasi dengan gaya hidup kota yang minim kebersamaan, sebenarnya mempunyai keinginan dan masih mencari kanalkanal untuk bersosialisasi . Hal ini dapat diperhatikan dari perkembangan pesat pengguna sosial media dan jumlah pemain game on-line yang manjadi medium untuk berkomunikasi (Nisrina, 2016).

Karya proyek Interactive Skatepark ini bertujuan untuk menanggapi kekosongan yang hadir dalam masyarakat, seiringnya dengan memberikan tidak hanya sebatas fasilitas atas dasar dari kebutuhan warga yang memerlukan ruang ketiga atau yang disebut sebagai 'Third place'. Tergolong dalam kategori entertainment dan commercial, pendekatan program sebagai basis dari Interactive Skatepark Setiabudi berdasarkan karakteristik warga Setiabudi dan sekitarnya, maka dari itu penekanan dari pengertian istilah Third place dipadukan dalam program-program interaktif untuk mengajak seluruh pengunjung agar mendapati dirinya saling berinteraksi dan menikmati ruang jeda disela-sela kegitan aktif dalam kesehariannya.

Secara tidak langsung kehadiran program ini yang dibangun diantara keramaian kota industry dapat secara perlahan menenangkan terjangan cenderung dari segi individu seseorang lebih memprioritaskan diri sendiri dan sedikit didapatinya minoritas yang tidak terpengeruh perihal tekanan social tersebut. Maka dari itu, proyek interactive skatepark setiabudi sekilas merupakan magnet yang memperkenankan warga mendapati keharmonisan dalam kehidupan social yang dapat arogansi kaum industrialism dan membentuk masyarakat yang kolektifisme daripada individualisme. Visi yang diangkat ialah memberikan serangkaian ruang yang bersifat interaktif, mengembangkan dampak positif dam hal social pada pengguna. Di tengah kesibukan rutinitas kota padat akibat pengaruh revolusi industrialism yang menimbulkan perbedaan dalam status dan kelas social, menjalar meluas dalam kota.

Beberapa dari misi yang akan dicapai dengan program yang hidangkan dituntun oleh 8 kriteria oleh teori Oldenburg (1989):

a. Memberi hiburan bagi warga terbebas dari ikatan politik, ekonomi

b. Meningkatkan hubungan social yang terjalin dalam masyarakat

c. Memberikan ruang untuk bernafas di tengah kota, sebuah ruang jeda untuk melepas semua kesibukan rutinitas masyarakat 
d. Menjadi ruang titik pertemuan yang menyenangkan yang interaktif

Manfaat proyek interaktif ini memberi dorongan kuat akan pengaruh terhadap pengembangan pribadi dalam berkelompok, yakni dalam kehidupanan social untuk pembentukan masyarakat sejahtera dan kuliatas lingkungan sehat dan harmonis.

\section{Urgensi Isu}

Bagi sebuah kota yang memiliki sejumlah individualis tinggi, hal ini menjadi sebuah isu yang tidak terlalu visible dalam waktu yang lama, maka berdampak negatif dalam segi solidaritas dikarenakan egoisme yang tidak terbatas, dan alhasil masyarakat perlahan sulit untuk bersosialisasi. Ciri-ciri masyarakat yang bersifat indivisualisme dapat dilihat dari beberapa fakor yakni dari kehidupan sehari-hari penduduk kota, tidak sedikit yang saling tidak mengenali tetangga baik di perumahan ataupun pada tempat tinggal dan tempat kerja vertikal.

\section{Pertanyaan Penelitian}

Bagaimana arsitektur, sebagai wadah, dapat mendorong sosialisme dari individualisme menjadi masyarakat kolektivisme diantaranya secara menanggung kebutuhan masyarakat semaksimal mungkin?

\section{Batasan Masalah}

Masalah dibatasi pada solusidan tanggapan terhadap isu gaya hidup masyarakat terutama milenial untuk memberikan gaya hidup yang lebih sehat melalui interactive skatepark.

\section{Tujuan Penelitian/Desain}

Tujuan atas penelitian dan perancangan ini adalah untuk menjadi ruang yang dapat melayani kebutuhan masyarakat dalam tingkat kota, meningkatkan hubungan sosial pada kawasan dan sekitarnya sebagai tanggapan atas isu, serta mengembangkan budaya masyarakat dan meningkatkan kualitas hidup.

\section{KAJIAN LITERATUR}

\section{Karakteristik dan Limitasi Third place}

Ruang neutral yang jauh dari first place (rumah) dan second place (tempat kerja) dimana kegiatan utama ialah berinteraksi bertukar pikiran dan cenderung makanan ditawarkan diantara kegitan tersebut.

8 Karakteristik yang menjelaskan apa itu third place menurut Oldenburg (1989):

- Neutral ground: tidak terikat dari segi politik, ekonomi, aspek lainnya, penggunjung tidak memiliki obligasi dan bebas untuk mendatangi tempat tersebut.

- Leveler: tidak memandang status, third place menerima semua kalangan tanpa syarat partisipasi.

- Dialogical: komunikasi sebagai kegiatan utama yang bersifat ramah dan menyenangkan.

- Accessibility and accommodation: selalu terbuka saat diperlukan dan memenuhi semua kebutuhan penggunjung.

- The regulars: memiliki pengunjung tetap yang mendasari karakteristik tempat namun juga menyambut pengunjung baru untuk merasa nyaman.

- A low profile: tanpa pemborosan atau hal yang berlebihan, kesederhanaan yang dapat menerima semua pengunjung dari berbagai latar belakang pengalaman hidup, memiliki kesan rumah bagi pengunjung.

- The mood is playful: menciptakan suasana yang ringan jauh dari adanya konflik atau pun pertentangan yang tidak menyenangkan. 
- A home away from home: menyediakan kehangatan seakan-akan merasa bagian dari komunitas, seperti rumah sendiri, di mana pengunjuk mendapati energi positif dari lingkungannya.

\section{Individualisme dan Kolektivisme}

Individualisme dicetuskan oleh Alexis de Tocqueville yang bermaksud pada gejala terisolasi individu dalam masyarakat akibat revolusi Perancis, lalu diteliti lebih lanjut oleh Hofstede (1980) yang memakai otonomi sebagai tolak ukur indeks individualisme dan juga kolektivisme. Individualisme - kolektivisme merupakan salah satu dari 5 work values (aspek) dalam teori Dimentsion Cultural yang Hofstede (1980) jabarkan, yaitu:

- Individualism vs. Collectivism

- Power Distance

- Uncertainty Avoidance

- Masculinity vs. Feminity

- $\quad$ Long Term vs. Short Term Time Oriented

Individualisme ialah suatu filsafat yang memiliki pandangan moral, politik atau social yang menekankan kepentingan tanggung jawab dan kebebasan sendiri, maka berkehendak pribadi unutk mencapai yang diingini. Sering kali tidak memperdulikan sekitar, termasuk intervensi keluar atau pun dari luar.

Tabel 1. Responden Riset

\begin{tabular}{|c|c|c|}
\hline Variable & $\mathrm{N}$ & $\%$ \\
\hline \multicolumn{3}{|l|}{ Education } \\
\hline Doctorate Degree & 1 & 0.0 \\
\hline Master's Degree & 82 & 4.0 \\
\hline Bachelor Degree & 680 & 33.6 \\
\hline Diploma & 294 & 14.5 \\
\hline Senior High School & 941 & 46.5 \\
\hline Junior High School & 27 & 1.4 \\
\hline \multicolumn{3}{|l|}{ Age } \\
\hline Below 25 years oid & 27 & 1.3 \\
\hline $25-30$ years old & 103 & 5.1 \\
\hline $31-44$ years old & 646 & 31.9 \\
\hline Over 44 years old & 1249 & 61.7 \\
\hline \multicolumn{3}{|l|}{ Sex } \\
\hline Male & 1662 & 82.1 \\
\hline Female & 363 & 17.9 \\
\hline \multicolumn{3}{|l|}{ Tenure } \\
\hline$<2$ years -2 years & 76 & 3.8 \\
\hline$>2-6$ years & 47 & 2.3 \\
\hline$>6-10$ years & 10 & 0.5 \\
\hline$>10-12$ years & 193 & 9.5 \\
\hline$>12-18$ years & 289 & 14.3 \\
\hline$>18$ years & 1410 & 69.5 \\
\hline \multicolumn{3}{|l|}{ Ethnicity } \\
\hline Javanese & 856 & 42.3 \\
\hline Sundanese & 98 & 4.8 \\
\hline Minangkabau & 102 & 5.0 \\
\hline Batak & 135 & 6.7 \\
\hline Balinese & 40 & 2.0 \\
\hline Malay & 131 & 6.5 \\
\hline Ambonese & 88 & 4.3 \\
\hline Others & 143 & 7.1 \\
\hline (Indonesian) & 432 & 21.3 \\
\hline
\end{tabular}


Individualisme berkaitan dengan masyarakat melalui ikatan individu yang tidak erat maka setiap orang masing-masin menjaga diri sendiri dan keluarganya. Sedangkan kolektivisme sebaliknya merupakan filsafat pendirian moral, politik, ideologi dan pandangan yang mementingkan social, maka kalangan ini berfokus pada kepentingan bersama, seperti perihal nasional segi politik, ekonomi dan pendidikan, berkaitan dengan masyarakat di mana sejak lahir dan seterusnya diintegrasikan ke dalam kelompok yang kuat dan kohesif, yang sepanjang hidup masnusia terus melindungi mereka dengan imbalan kesetiaan yang tidak perlu dipertanyakan lagi.

Dalam Paper from the International Association for Cross-Cultural Psycholocy Conferences, Wustari L. H. meriset kembali tiap work values dengan mengandalkan teori Hofstede (1980). Wustari L. H. mengambil data dari sejumlah 2025 responden dari jangka usia, latar edukasi, dan lama bekerja dalam perusahaan yang bervariasi. Di samping ini merupakan profil responden, berasal lebih dari 7 etnis terbesar di Indonesia yang memiliki budaya berbeda sebagai latar belakang. Sebesar $69.5 \%$ dari responden sudah bekerja dalam perusahaan lebih dari 18 tahun. Responden dari Jawa setinggi $42.3 \%$, sebanyak $82.1 \%$ jenis kelamin lelaki sebanyak $61.7 \%$ usia diatas 44 tahun, dan $98.6 \%$ sudah lulus SMA. Kuesioner yang dikembangkan oleh Wustari dari versi Hostede sudah di validasikan dengan factor analisis dan realibilitas Koefisien Cronbach's Alpha. Hasil di bawah ini menunjukan bahwa terdapat peningkatan pada aspek Indvidualism-Collectivsm, Uncertain Avoidance dan Masculinity, sedangkan penurunan dalam Power Distance.

Tabel 2. Work values of the Company

Work Values of the Company

\begin{tabular}{clcl}
\hline No & Work Values & Score & Category \\
\hline 1 & Individualism - Collectivism & 62 & Individualism \\
2 & Power Distance & 61 & High Power Distance \\
3 & Uncertainty Avoidance & 49 & Low Uncertainty Avoidance \\
4 & Masculinity - Femininity & 65 & Masculinity \\
5 & Time Orientation & 62 & Future Orientation \\
\hline
\end{tabular}

Sumber: Papers from IACCP Conferences, 2013

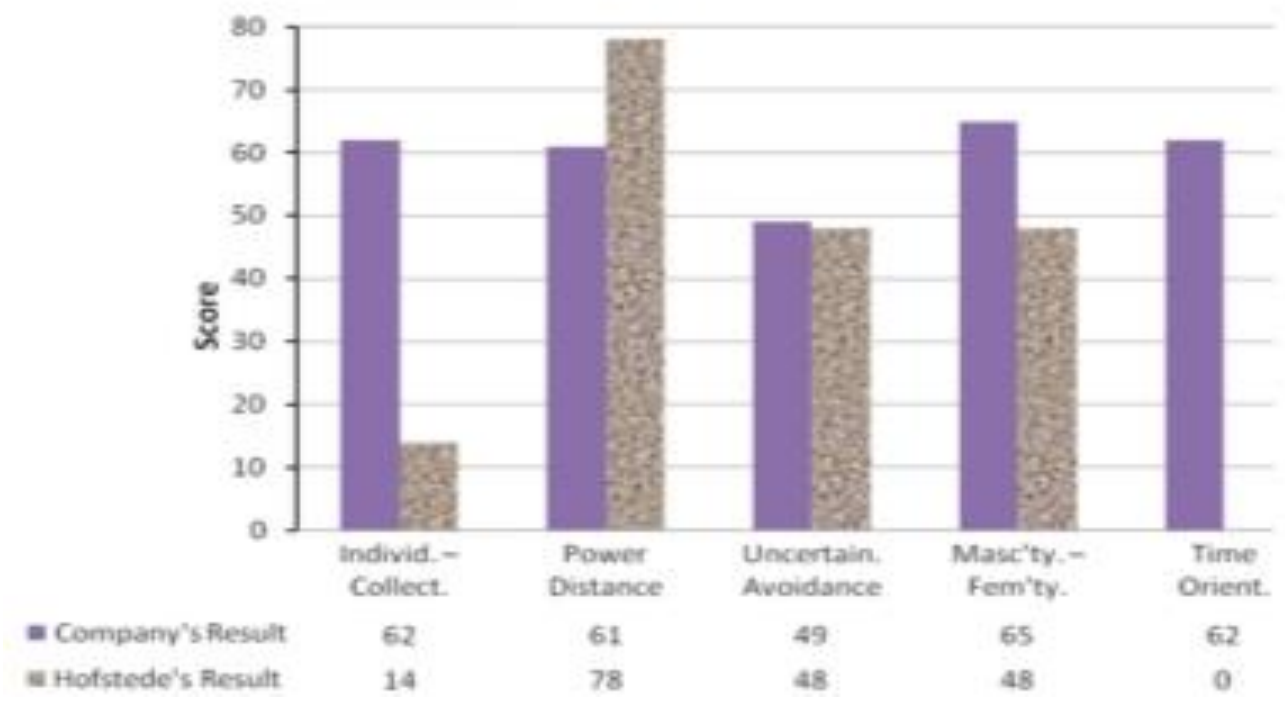

Gambar 1. Indonesian Work Values Bar chart

Sumber: Papers from IACCP Conferences, 2013 
Hasil yang diteliti ini menimbulkan pertanyaan sejauhmana terjadinya perubahan kultur yang bergeser di Indonesia atau disebabkan oleh mencerminkan efek dari kultur organisasi pada pegawai. Pada riset ini juga menunjukan bahwa pergeseran work values pada I-C terjadi dikarenakan tantangan dan minat tinggi dalam berkompetisi di mana masyarakan cenderung focus pada diri masing-masing dari pada perihal mengenai grup atau komunitas sekitarnya. Selain itu juga menunjukkan bahwa faktor sosial budaya, yakni sosial, ekonomi, historis, dan ideologis, dapat membentuk dan mempengaruhi perilaku manusia. Tidak ada masyarakat atau budaya adalah homogen, di mana Budaya itu dinamis, tidak konsisten, serta beragam. Maka, hal ini ini merupakan proses dimana budaya mempengaruhi individu atau kelompok perilaku secara sangat jelas (Furnham, 2006).

\section{Definisi Skatepark}

Antara pertengahan 1970-an dan awal 1980-an ratusan skatepark beton bermunculan hampir di setiap negara bagian di Amerika Serikat. Desain menggunakan campuran dari mangkuk, snake runs, waduk semen, pipa penuh, pipa setengah, dan pipa seperempat dari semua bentuk dan ukuran. Bagi para skaters, skating bukanlah olahraga, itu adalah cara hidup, dan tidak ada peraturan taman, hukum, peraturan pad, skuter anak-anak, orang tua, atau larangan penjaga taman. Pada tahun 1970, perkembangan skatepark mulai terbentuk hingga pada tahun 1990 perkembangan melambat. Namun kembali pesat pada tahun 1997 saat dibangunnya skatepark di Senayan, dan setahun kemudian terbentuk komunitas Indonesian Skateboarding Association (ISA) yang menjadi induk organisasi, dan pertandingan nasional dilaksanakan hingga kini. Fenomena perkembangan ini membawa Indonesia menembus tingkat Asia (Ginanjar Firdaus, 2007).

Setelah itu skatepark menjadi salah satu jenis ruang terbuka publik di kota-kota bagi anak muda dan remaja, dan kegiatan ini sendiri berperan sebagai suatu hal yang menghubungkan para remaja saling berinteraksi dan mengekspresikan dirinya.

\section{METODE}

Metode pengumpulan data menggunakan metode studi literatur, studi kasus, tinjau lokasi lapangan, media cetak dan online. Tahap desain berawal dari hadirnya isu kota, studi literatur dan studi kasus akan variasi program serupa, tinjauan lokasi, analisis kawasan pada tingkat makro, meso dan mikro, studi massa, juga metode trans programming berasal dari Bernad Tschumi. Survei melalui buku-buku literatur, e-journal, dan Badan Pusat Statistik, serta tinjauan observasi pada kawasan Tanah Abang, Menteng, Setiabudi, dan beberapa third place serupa dengan program yang diusulkan, diantaranya Aborea Cafe, Avenue of the Stars Kemang Village, Kokonut \& Curtain, ForesThree, Taman Menteng, dan Skatepark Spot Budaya. Metode yang diangkat sebagai panduan merancang adalah:

a. Tipologi sebagai pendekatan awal untuk mendalami pemahan tipe kegiatan diluar kehadiran ruang sebagai model. dalam "On Adam's House Paradise", konsep tipologi merupakan pengolahan pikiran dalam berargumen. Memasuki tipologi dalam ruang kegiatan, ialah dasar dari pemahaman atas terbentuknya ruang akibat kehadiran kegiatan lebih dahulu, maka menganalisis atasan ruang gerak akan mengaitkan nama ruangan. Sebaliknya nama tidak dapat diartikan sebagai tipe, hanyalah model di mana perlu diterlusuri tipenya. Seperti contohnya sekolah bukanlah tipe kegiatan, tetapi mengajar dan belajar ialah tipe kegiatannya, dan dari penelusuran tipe ini dapat dikembangkan hasil batas ruang mengajar-belajar.

b. Trans-programming yang membekali proses perancangan dalam mengeksperimen hubungan antara space dan event. Bernard Tschumi mengungkapkan, "Jika arsitektur adalah konsep dan pengalaman, ruang dan penggunaan, struktur dan citra yang dangkal... maka arsitektur harus berhenti untuk memisahkan kategori-kategori ini dan alih-alih menggabungkannya ke dalam kombinasi program dan ruang yang belum pernah terjadi sebelumnya." Dari sini terbentuk pemikiran cross-programming dan 
disprogramming, di mana aspek-aspek program yang kompleks dan dapat saling bertentangan dari realitas kontemporer, dipadukan, hal ini dapat me-redefine makna arsitektur. Salah satu contohnya yaitu gagasan surelias, "the meeting of umbrella and sewing machine on the dissecting table." Teori mengenai hubungan antara ruang (space) dan peristiwa (event) menghasilkan tiga kemungkinan yang berbeda: saling mendukung / corresponding one another (form ever follows function), saling bertentangan satu dan yang lain, dan saling mengabaikan satu sama lain. Proses eksperimental mengenai hubungan antara keduanya yang mengandalkan 'pemisahan' atau yang dimaksud 'disjunctions' didesain untuk mengubah dampak dari subyek yang dimanipulasikan dengan mempercepat dan mengintensifikasikan hilangnya kepastian, dari pusat, dan dari sejarah.

\section{DISKUSI DAN HASIL}

\section{Analisa Tapak}

Pemilihan lokasi berdasarkan hasil korelasi antara isu individualisme yang timbul dan analisis kawasan akan aktivitas dan budaya sekitar tapak. CBD utama Jakarta, dan juga salah satu CBD yang paling pesat perkembangannya di Asia-Pasifik yang menyerupai bentuk segitiga dikenal sebagai Jakarta Golden Triangel atau yang disebut sebagai Segitiga Emas Jakarta, yang terbentang dari jakarta pusat ke Jakarta Selatan, menampung sebagian besar bisnis, keuangan, dan perusahaan diplomatik. Utara-Barat Daya, Rasuna Said dari sisi UtaraTenggara, dan Gatot Subroto dari sisi Timur Barat, dipenuhi sejumlah besar gedung pencakar langit tertinggi. Tapak berada di zona campuran, KDB sedang, dikelilingi gedung perkantoran, dekat dengan kompleks perumahan. Berikut tabel zonasi RDTR Tapak:

Tabel 3. Zonasi RDTR Tapak

\begin{tabular}{ll}
\hline Luas Tapak & $2475 \mathrm{~m}^{2}$ \\
\hline KDB 55\% & $1361 \mathrm{~m}^{2}$ \\
\hline KDH 30\% & $742 \mathrm{~m}^{2}$ \\
\hline KLB 3 & $7425 \mathrm{~m}^{2}$ \\
\hline KB & 8 lantai \\
\hline KB & $1361 \mathrm{~m}^{2}$ \\
\hline KTB 55\% & $1361 \mathrm{~m}^{2}$ \\
\hline
\end{tabular}

Sumber: Perda DKI Jakarta No.1 Tahun 2014

Dukuh Atas merupakan kawasan Transit Oriented Development di mana sudah banyak tersedia fasilitas-fasilitas yang berhasil dibangun, kualitas pedestrian yang sangat baik, jalur untuk sepeda pada pedestrian dan jalan raya, serta transportasi umum yang terintergrasi. Sejumlah besar transportasi umum diantaranya ialah MRT, LRT Jakarta, LRT Jabodetabek, LRT commuter Line, Railink Bandara, Bus Transjakarta, Metrotrans, Metromini, dan (akan hadir) Royal Trans. MRT dari stasiun Lebak Bulus Grab hingga MRT Bundaran HI sudah beroperasinal tanpa masalah dan kini stasiun fase bersikutnya sedang dalam proses pembangunan untuk melengkapi kebutuhan akan transportasi umum. Dalam radius $1 \mathrm{~km}$, pejalan kaki dapat menggapai 2 stasiun MRT; stasiun MRT Dukuh Atas BNI dan stasiun MRT Setiabudi Astra.

Semenjak penyelenggaraan Asian Games 2018 dan Asian Para Games 2018, penetapan jalur ganjil genap yang diperluas ke berbagai kawasan di Jakarta dan adanya perpanjangan ganjil genap yang baru ini dilakukan berdasarkan Peraturan Gubernur DKI Jakarta No.155 Tahun 2018, yaitu mengenai Pembatasan Lalu Lintas dengan Sistem Ganjil-Genap yang mulai diberlakukan mulai pada tanggal 2 Januari 2019. Jadwal ganjil genap yang baru ini diterapkan setiap hari Senin sampai Jumat di pagi hari pada pukul 06.00 WIB -10.00 WIB dan pukul 16.00 WIB - 21.00 WIB. 

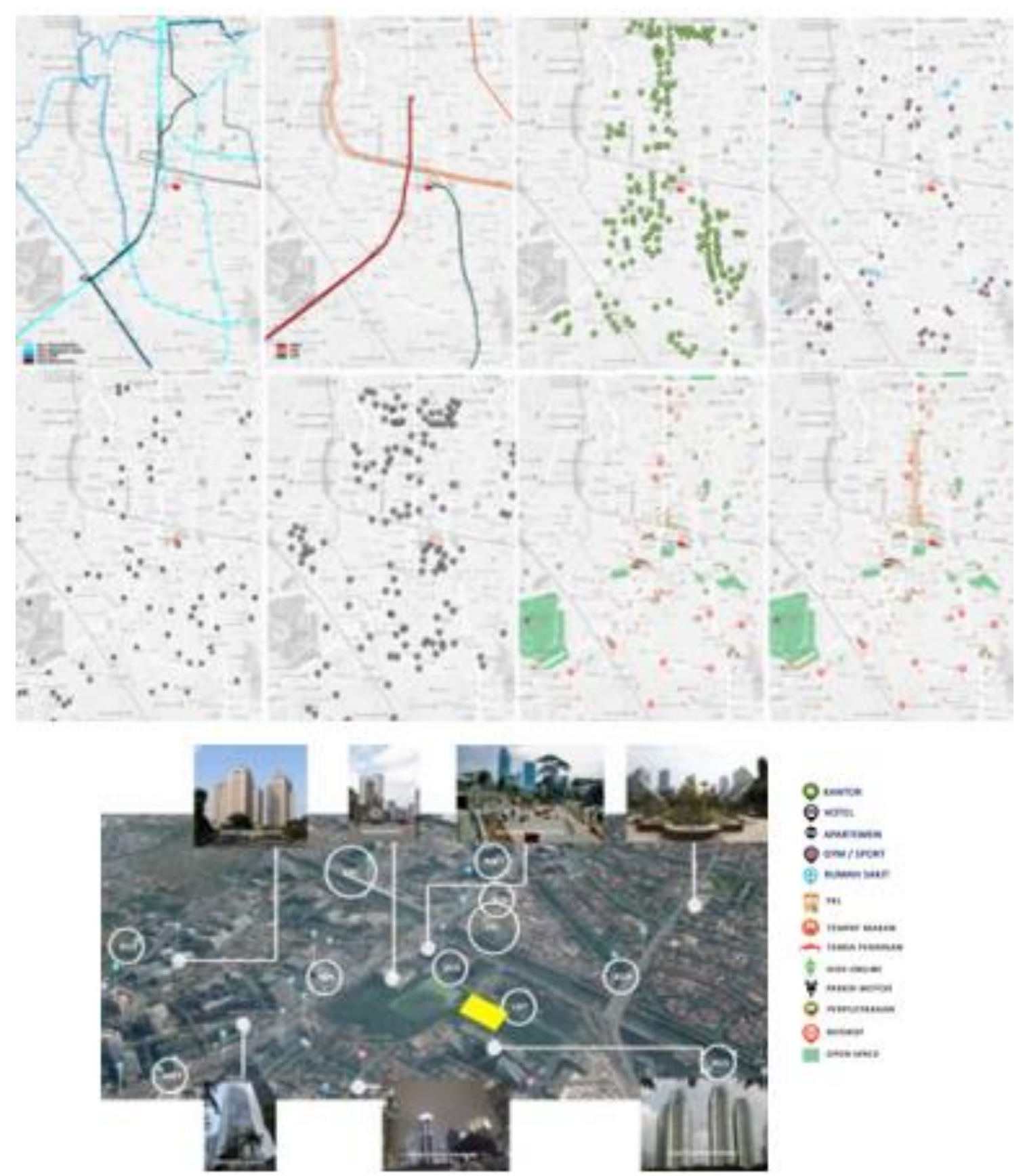

Gambar 2. Analisis Makro, Meso, Mikro

Sumber: Penulis, 2019

Hal ini berdampak besar pada pembatasan akses jalan tersebut dapat terkontrol dalam tingkat kepadatan mobolitas, alhasil adanya peringanan pada tingkat kemacetan pada kawasan tersebut. Selain itu setiap hari Minggu rata-rata dari pukul 06.00-11.00 WIB, dari Jl. Sudirman hingga Jl. MH Thamrin di tutup dari semua kendaraan umum yang diperuntukan untuk HBKB (Hari Bebas Kendaraan Bermotor) seperti pada Gambar 3. 


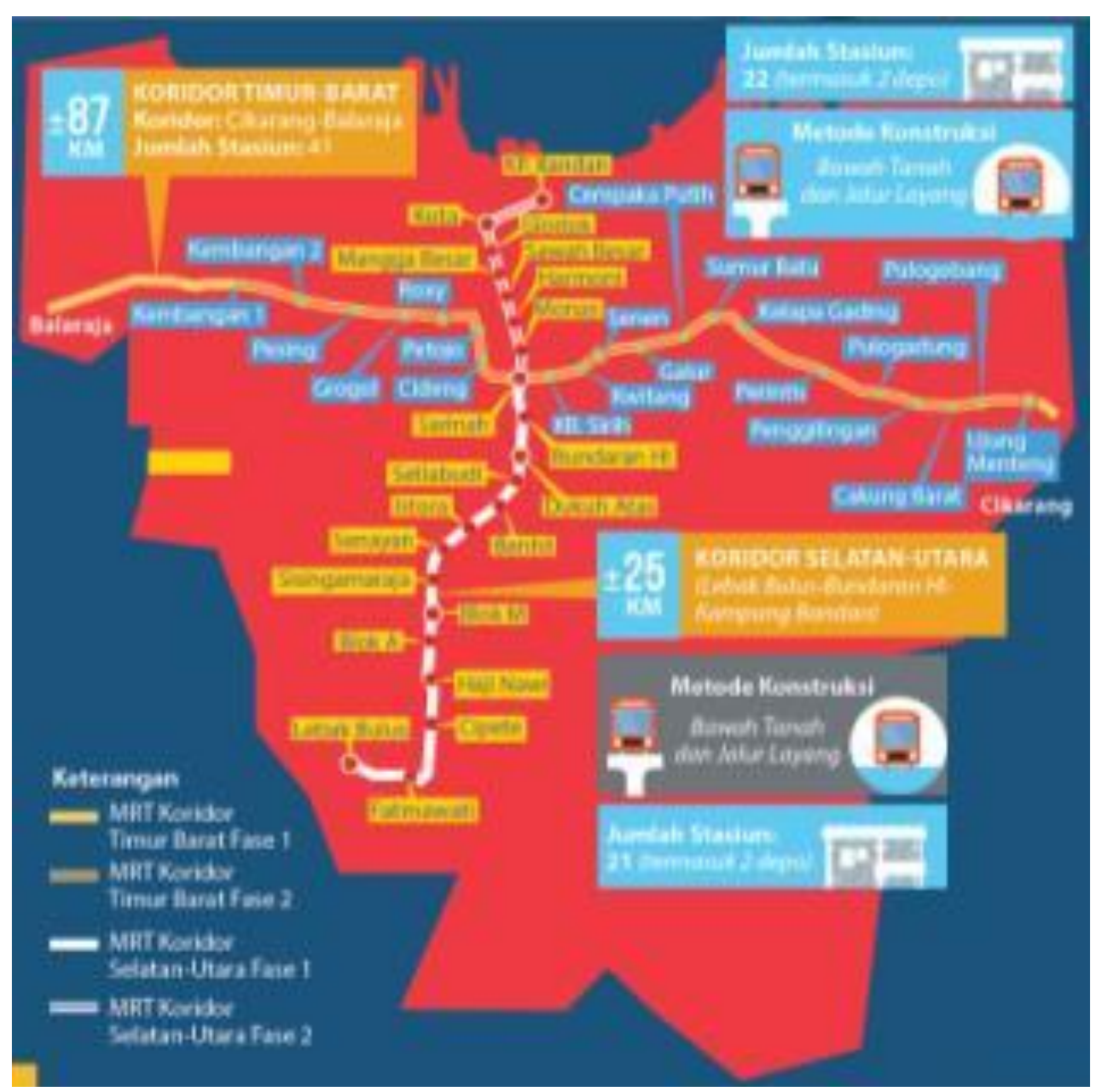

Gambar 3. Jalur MRT

Sumber: strategi, 2019 (edited)

Tapak berada berdekatan dengan Jendral Sudirman dikelilingi oleh tiga kecamatan yaitu kecamatan Setiabudi, kecamatan Tanah Abang, dan kecamatan Menteng. Berangkat dari hirarki jalan di mana jalan Sudirman diklasifikasian sebagai Jalan arteri berstatuskan jalan nasional, melayani angkutan utama dengan tujuan perjalanan jarak jauh, kecepatan rata-rata tinggi dan jumlah jalan masuk yang dibatasi secara efisien oleh regulasi lalu lintas. Pada sisi jalan, baru dibuka taman dukuh atas yang didesain memfasilitasi skateboard, anjungan, dan taman tropis mini. Taman ini menjadi daya tarik masyarakat, terutama pada hari Minggu saat HBKB dan menerima apresiasi tinggi dalam kegiatan berolahraga. Kemudian dari mapping analisis kawasan, terdeteksi sejumlah besar tempat makan informal, yakni pedagang kaki lima berupa warung, gerobak kayu, pedagang minuman sepeda yang berserakan di antara gedung-gedung pada pinggir jalan kolektor. Diantaranya merupakan suatu bentuk ruang ketiga bagi beberapa masyarakat yang bekerja pada kawasan tersebut. Hasil tinjauan observasi terhadap kawasan mengemukakan sejumlah PKL yang meramaikan pedestrian hingga malam hari, dan lebih banyak yang mulai bergadangan pada senja hari.

\section{Program}

Dari hasil mapping, penghitungan luasan ruang-ruang tersebut dibandingkan untuk dijadikan persentase secara garis besar, yang akan menunjukan proporsi kegiatan. Sedangkan pada hari Minggu persentase ruang ketiga eksisting kawasan berubah akibat pengaruh HBKB. Jalan pedestrian yang menjadi koridor bazar termasuk dalam kategori makanan, Bundaran $\mathrm{HI}$ termasuk dalam aspek taman karena sifat serupa yaitu open space 
di mana warga duduk berantai menikmati suasana air mancur, sedangkan lajur kendaraan digunakan sebagai rute berjalan kaki, berlari, bersepeda, dog-walking, dan kegiatan aktif masuk dalam kegiatan olahraga. Hasil persentase data tersebut disesuaikan membentuk program kegiatan.

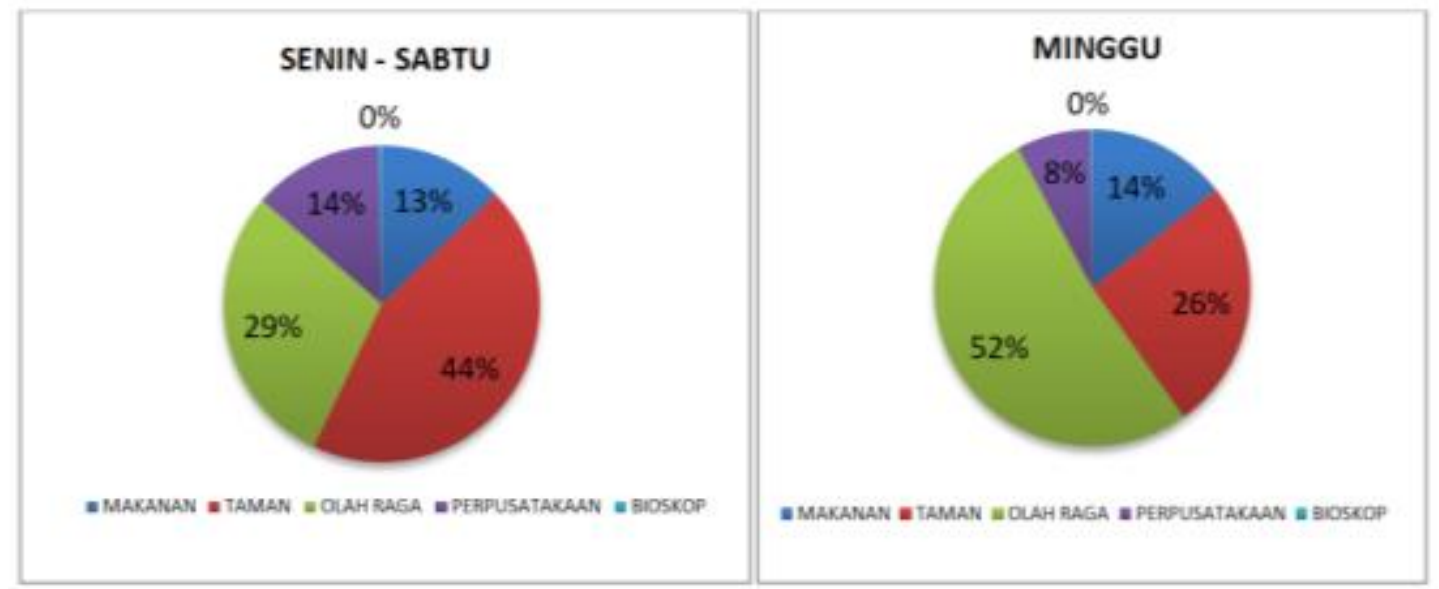

Gambar 4. Persentase proporsi kegiatan Sumber : Penulis, 2019
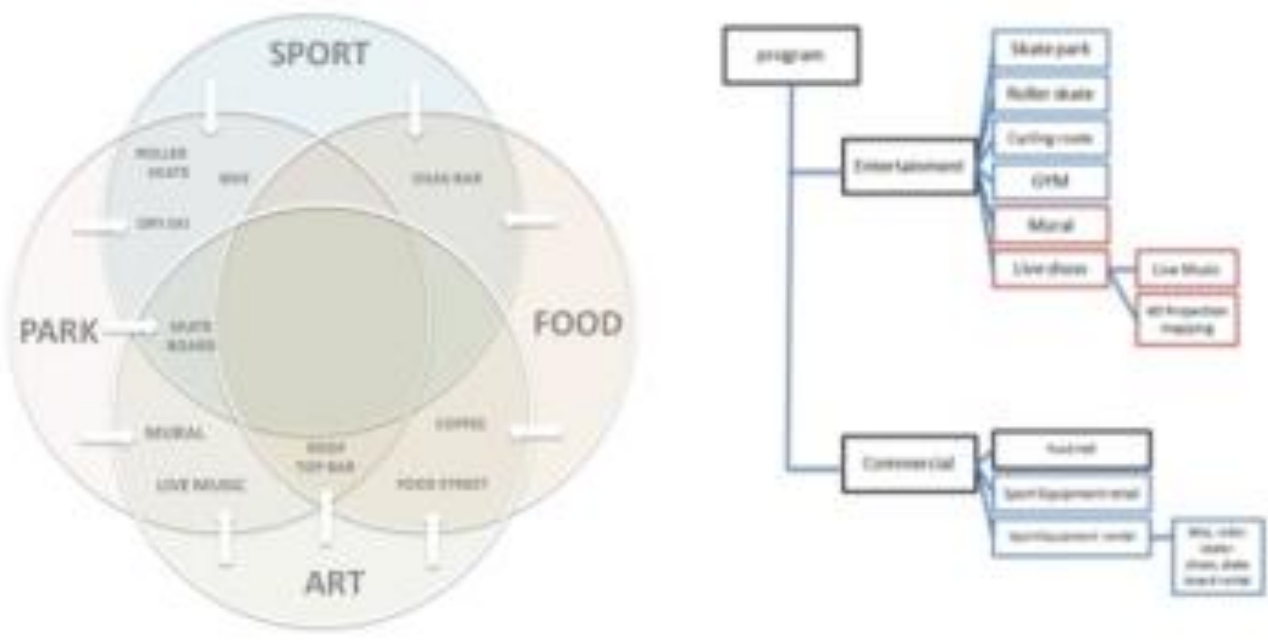

Gambar 5. Program Interactive Skatepark Sumber : Penulis, 2019

Dari diagram program di atas mengandalakan teori tipologi dan trans-programming, perancangan ditekankan pada hubungan antara space dan event, serta pembentukan ruang berdasakan sumber konsep Edward T White (1987). Menggangkat diantaranya 4 unsur simpulan analisis budaya kawasan ini, muncul beberapa kegiatan yang dibawa menjadi program. Ruang ketiga ini menawarkan tidak hanya perpanjangan-tangan atas skateboard, bikes, dan roller skate, namun juga memperkenalkan program yang masih asing yaitu $d r y$ ski.

\section{Konsep dan Bentuk Rancangan}

Konsep-konsep perancangan ruang dari Edward T White menjadi pedoman dalam penataan, sirkulasi, dan berbagai unsur pembentukan ruang hingga keseluruhan bangunan. Unsur pembentukan ruang seperti hasil dari bidang garis partisi, pembatas, pencahayaan, elevasi dapat memberi kesan suasana yang nyaman seiring membangun Third place. Berikut diagram konsep sistem sirkulasi dan pergerakan dalam bangunan: 


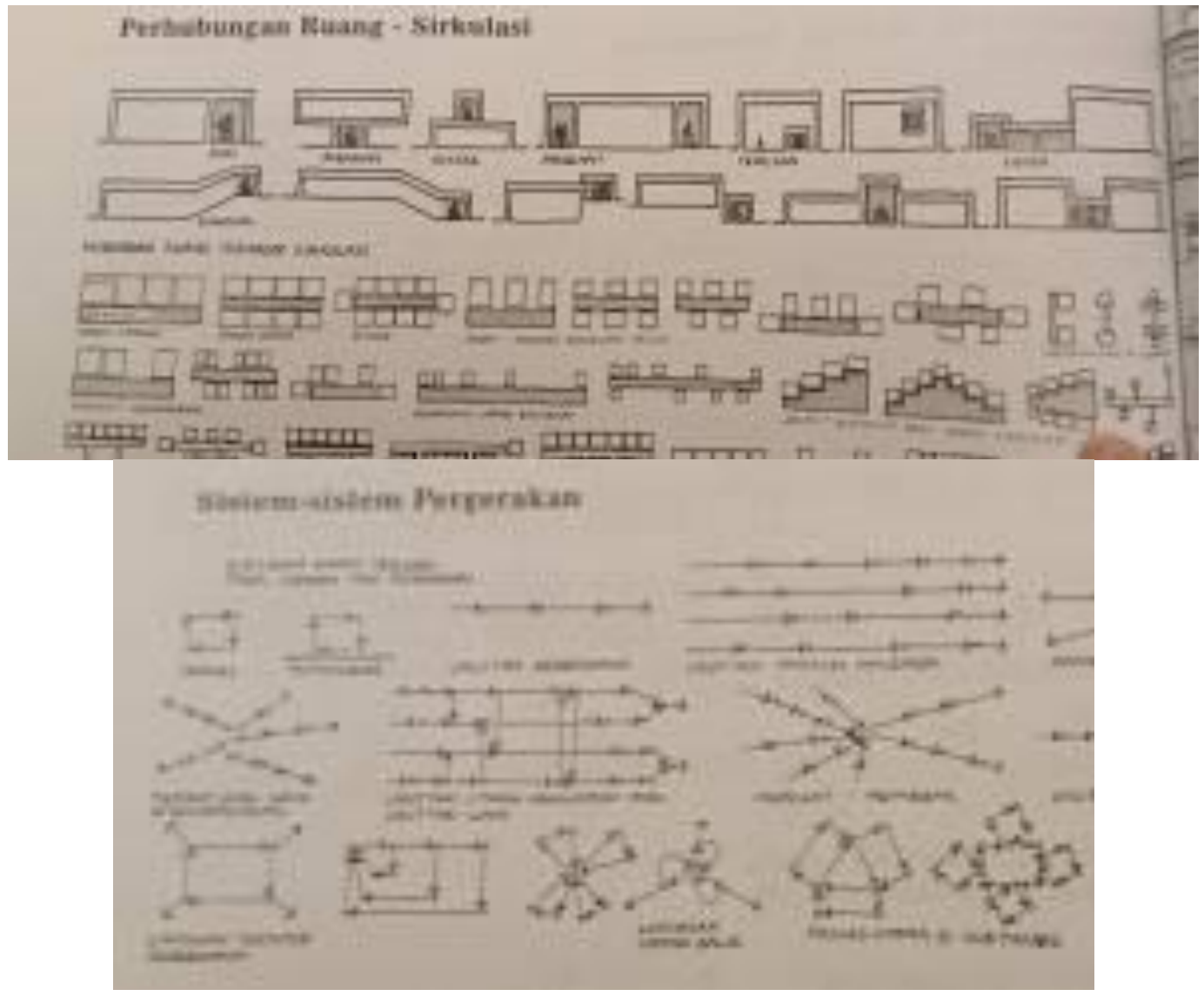

Gambar 6. Sistem sirkulasi dan pergerakan dalam bangunan Sumber : Concept Sourcebook, 1987

Tepat pada bagian depan tapak menghadap Jl, Setiabudi tengah merupaakn statiun LRT yan memiliki ketinggian setinggi 8 meter terbetang sepanjang jalan tersebut, maka dari sini, dibuat bentukan ruang yang mengundang baik bagi pengendara maupun pedestrian mengandalakn konsep-konsep Edward T White (1987). Sisi depan Proyek interaktif Skatepark dibuat slanted mengarah pada jempatan lajur LRT, membentuk rangkulan dengan memakai skala besar. Selain itu konsep gubahan masa berasarkan analisis tapak, menyampingi sisi terik matahari Barat dan Timur, menghadap pada arah mata angin Utara.

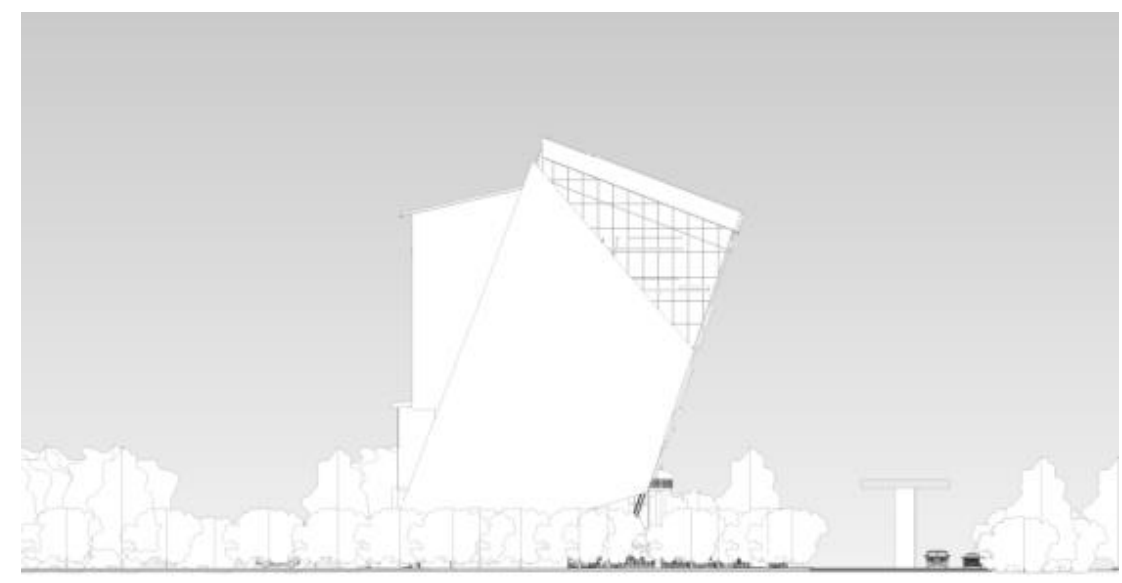

Gambar 7. Massa Bangunan terhadap LRT Sumber : Penulis, 2019 


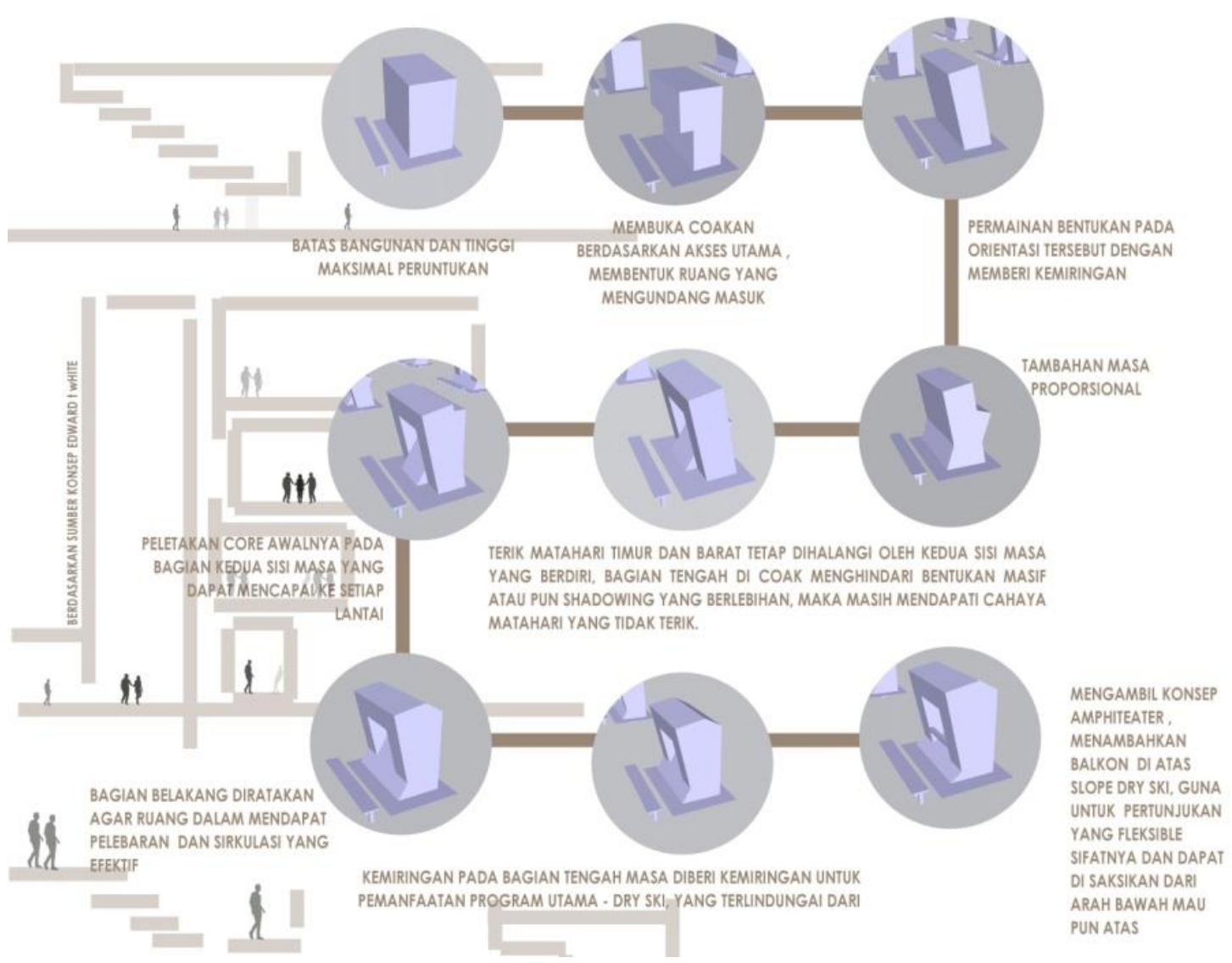

Gambar 8. Design Scheme Interactive Skatepark

Sumber : Penulis, 2019

\section{KESIMPULAN DAN SARAN}

\section{Kesimpulan :}

a. Perilaku pada individu dan masyarakat bertimbal balik saling mempengaruhi, faktor ekternal terutama yang memicu pembangunan karakteristik seseorang. Rutinitas kesibukan kota secara tidak langsung berdampak dan membangun pribadi yang mengarah pada individualis sifatnya, alhasil minimnya interaksi sosial membentuk masyarakat yang pasif.

b. 'Third place' dapat memberikan dampak-dampak positif terhadap masyarakat, serta secara individu merupakan sebuah ruang pemberhentian sejenak untuk menemukan jati diri di luar ikatan identitas yang terjalin kaku. Di sini, peran third place merupai sebagian wujud ketika memandang kehidupan.

c. Mengandalkan 8 kriteria mengertian third place serta analisis kawasan dan analisis aktivitas pengguna sekitar, didapati hasil persentase proporsi kegiatan yang merupai dengan third place namun belum sepenuhnya merupakan third place.

d. Pemilihan lokasi berdasarkan hasil korelasi dengan isu. Kecamatan Setiabudi menjadi titik lokasi yang belum memiliki wadah yang merupakan third place sepenuhnya. Berada sepanjang jalan Sudirman yang merupakan jalur CFD (Car Free Day) dan sistem TOD yang sangat kuat, maka kriteria ynag tepat untuk memfasilitasi kebutuhan third place.

e. Dipandu dengan teori tipologi ruang untuk penentuan aktivitas, trans-programming untuk memanipulasi / permainan hubungan space and event, serta konsep-konsep dari Edward T white (1987) yang bertahap membentuk ruang hingga keseluruhan bangunan. 


\section{Saran:}

Sesuai dengan hasil evaluasi desain, penulis menyarankan program-program interaktif sesuai dengan kondisi tapak dan sekitar, ruang jeda dalam kategori entertainment dan commercial yang berada dalam hiruk pikuk kesibukan kota, guna mengembangkan pribadi yang hidup secara berkelompok hingga meningkatkan nilai hubungan sosial dan menciptakan keharmonisan diantaranya.

\section{REFERENSI}

Duncan M., Jullan A. (2015). Sharing Cities: A Case for Truly Smart and Sustainable Cities. Cambridge: The MIT Press.

Ginanjar, F. (2007). Peluang Pengembangan Public Skatepark di Ruang Terbuka Publik Pusat Kota Semarang. Diakses Oktober 2, 2019. Diakses dari https://core.ac.uk/download/pdf/11704944.pdf

GOR. (2016). Orang Kota Jadi Individualis karena Eksternal. Diakses September 9, 2019. Diakses dari https://www.beritasatu.com/megapolitan/382531/orang-kota-jadi-individualiskarena-faktor-eksternal

Liputan 6. (2013, Januari 30). Psikolog: Macet Ibukota Bikin Orang Jadi Individualis. Diakses September 9, 2019. Diaskses dari https://www.liputan6.com/

Mangundjaya, W. L. H. (2013). Is there cultural change in the national cultures of Indonesia? In Y. Kashima, E. S. Kashima, \& R. Beatson (Eds.), Steering the cultural dynamics: Selected papers from the 2010 Congress of the International Association for Cross-Cultural Psychology. https://scholarworks.gvsu.edu/iaccp_papers/105/

Montgomery, C. (2013). Happy City: Transforming Our Lives Through Urban Design. United States, Canada, UK: Farrar, Straus and Giroux, Random House, Penguin Books.

Nisrina, A. (2016, Agustus 31). Orang Kota Pada Dasarnya Tidak Individuali. Diaskses September 13, 2019. Diakses dari https://satuislam.org/

Republika. (2016, Agustus 30). Ini Penyebab Orang Kota Sering Dicap Individualis.Diakses September 13, 2019. Diaskses dari https://nasional.republika.co.id/berita/nasional/umum

Oldenburg, R. (1989). The Great Good Place: Cafes, Coffee Shops, Community Centers, Beauty Partors, General Stores, Bars, Hangouts, and How They Get You Through the Day. New York: Paragon House.

Soros, G. (2006). Public Affairs. The Age of Fallibility. New York.

Susana ,T. (2006). Evaluasi Terhadap Asumsi Teoritis Individualisme dan Kolektivisme: Sebuah Studi Meta Analisis. Jurnal Psikologi. 33 (1). DOI: 10.22146/jpsi.7084.

Tschumi, B. (1991). Architecture and Disjunction. Cambridge: The MIT Press.

Tjahjono, G. (2000). Metode Perancangan Suatu Pengantar untuk Arsitek dan Perancang. Depok: Universitas Indonesia.

White, E. T. (1987). Concept Sourcebook. Bandung: Intermatra. 
